\section{Effects of New Cultivars of Ninebark on Feeding and Ovipositional Behavior of the Specialist Ninebark Beetle, Calligrapha spiraeae (Coleoptera: Chrysomelidae)}

\author{
Emily G. Tenczar and Vera A. Krischik ${ }^{1}$ \\ Department of Entomology, University of Minnesota, 219 Hodson Hall, 1980 \\ Folwell Avenue, St. Paul, MN 55108
}

Additional index words. Physocarpus opulifolius, resistance, anthocyanins, pest management

\begin{abstract}
Two newly developed cultivars of ninebark [Physocarpus opulifolius (L.) Maxim.], a yellow-leaved cultivar called 'Dart's Gold' and a purple-leaved cultivar called 'Monlo', were compared with the native for resistance to feeding and oviposition by the specialist ninebark beetle [Calligrapha spiraeae (Say)]. When offered the choice between two types of ninebark, beetles statistically preferred native $(P<0.0001)$ and 'Dart's Gold' $(P<0.0001)$ over 'Monlo', but showed no preference between native and 'Dart's Gold' $(P=\mathbf{0 . 0 7 4 3})$. Long-term performance bioassays showed significantly more eggs on 'Dart's Gold' than 'Monlo' $(P=0.0468)$. 'Monlo' contained the most anthocyanins $(P<0.0001)$ and chlorophyll $B(P<0.0001)$ and the least total nitrogen $(P=0.0283)$ and Kjeldahl nitrogen $(P=0.0014)$. Anthocyanins are known to act as feeding deterrents and bind with nitrogen, which may explain why beetles avoided feeding on 'Monlo' in preference tests.
\end{abstract}

The nursery industry is interested in producing plants resistant to insects to reduce pesticide use and prevent economic loss. Programs range from traditional breeding (Painter, 1951) to mechanisms of induced defense (Zavala and Baldwin, 2006) to the roles of genes in plant resistance (Smith, 2005; Smith and Boyko, 2007). Studies on plant-insect coevolutionary theory may help explain what types of phytochemicals may be investigated in traditional breeding programs to develop plants resistant to specialist leaffeeding beetles (Coleoptera) and moths (Lepidoptera). Coevolutionary theory argues that new phytochemicals in a plant may permit the plant to escape from herbivory by confusing the insect with the novel chemical. Specialist herbivores use chemicals as behavioral, feeding, and ovipositional cues (Ehrlich and Raven, 1969; Futuyma, 2000). The theory speculates that herbivores are deterred by qualitative compounds that are toxins (less than $2 \%$ dry weight) such as alkaloids, phenolic glycosides, and furanocoumarins (Rhoades, 1979). However, specialist insects become physiologically (cytochrome P-450 systems for detoxifying phytochemicals) and behaviorally (feeding, oviposition) adapted to these toxins (Beren-

\footnotetext{
Received for publication 28 Dec. 2006. Accepted for publication 21 May 2007.

We thank Undergraduate Research Opportunities Program (UROP), University of Minnesota, for funding part of this research.

${ }^{1}$ To whom reprint requests should be addressed; e-mailkrisc001@umn.edu.
}

baum and Zangerl, 1993). In contrast, quantitative compounds ( $5 \%$ to $20 \%$ dry weight) such as anthocyanins, polyphenols, and tannins are more difficult for specialists to adapt to because they often bind to nitrogen, reduce nitrogen availability, and slow insect development (Feeny, 1970).

Data support the premise that specialist insects use qualitative compounds as behavioral, feeding, and ovipositional cues. Bronze birch borer (Agrilus anxius Gory) used rhododendrol in bark of birch (Betula sp.) as an attractant (Santamour, 1999). The willow leaf beetle (Chrysomela aeneicollis Schaeffer) was attracted to salicylate in Sierra willow (Salix orestera Schneid.) (Rank, 1992). Black cottonwood (Populus trichocarpa Torr. \& Gray) contained salicin, which was sequestered and transformed into the larval defensive chemical salicylaldehyde in cottonwood leaf beetle (Chrysomela scripta F.) (Warren et al., 2002).

Quantitative compounds are considered in plant insect coevolutionary theory to be feeding deterrents, even to specialist insects (Rhodes and Cates, 1976). In quaking aspen (Populus tremuloides Michx.), higher tannin levels decreased cottonwood leaf beetle larval growth rate by $30 \%$ (Donaldson and Lindroth, 2004). In white oak (Quercus alba L.) and black oak (Q. velutina Lam.), fewer specialists such as weevils (Attelabus sp.) (Curculionidae), southern oak dagger moth [Acronicta increta Grote (Noctuidae)], and the moth Chionodes pereyra Clarke (Gelechiidae) were found on individual trees with higher tannin concentrations in the canopies (Forkner et al., 2004). In cotton (Gossypium hirsutum L.), chrysanthemum (anthocyanin), gossypol (polyphenol related to tannins), and other anthocyanins decreased feeding and survival of tobacco budworm [Heliothis virescens (F.)] (Hedin et al., 1983).

Anthocyanins, one class of flavonoids, produce red and purple pigments and were reported to reduce herbivory (Close and Beadle, 2003; Harborne and Williams, 2000; Kursar and Coley, 1992; Simmonds, 2003). Correlations were reported between anthocyanin and total phenols (Close et al., 2001; Lee and Lowry, 1980), low levels of chlorophyll (Dodd et al., 1998; Krause et al., 1995), and low levels of nitrogen (Skillman et al., 1996). Feeding by the pyralid moth eggplant borer (Leucinodes orbonalis Guenée) was lower on cultivars of eggplant (Solanum melongena L.) with higher levels of anthocyanins, phenolic compounds, and glycoalkaloids (Bajaj et al., 1989). In arabidopsis [Arabidopsis thaliana (L.) Heynh.], feeding by fall armyworm [Spodoptera frugiperda (JE Smith)] was lower on purple leaves $[0.38 \pm 0.03$ absorbance units (AU) of anthocyanins] compared with green leaves with purple veins $(0.29 \pm 0.03 \mathrm{AU})$ or green leaves $(0.023 \pm 0.003 \mathrm{AU})$ (Johnson and Dowd, 2004). Bronze wild radish (Raphanus sativus L.) flowers containing anthocyanins were fed on less than white or yellow flowers by imported cabbageworm [Pieris rapae (L.)], beet armyworm [Spodoptera exigua (Hübner)], cabbage aphid [Brevicoryne brassicae (L.)], western flower thrips [Frankliniella occidentalis (Pergande)], and grey field slug [Agriolimax reticulatus (Müller)] (Irwin et al., 2003).

Breeding resistant plants to specialist insects should involve the development of cultivars with novel qualitative chemicals or increased levels of quantitative chemicals that bind with nitrogen and reduce its availability in food. Ninebark (Physocarpus opulifolius) (Rosales: Rosaceae) is a hardy shrub ranging from Quebec south to Tennessee that grows along riverbanks in sandy soil (Wheeler and Hoebeke, 1979, 1985). Nurseries bred ninebark for atypical leaf color: a purple-leaved cultivar called 'Monlo' and yellow-leaved cultivar called 'Dart's Gold'. The purplish leaves of 'Monlo' may be higher in anthocyanins, which can be feeding deterrents (Harborne and Williams, 2000; Simmonds, 2003) to the specialist ninebark beetle (Calligrapha spiraeae) (Coleoptera: Chrysomelidae). The objectives were to evaluate among two cultivars and native: 1) herbivore leaf preference, 2) herbivore fecundity in long-term rearing, and 3) leaf chemistry.

\section{Materials and Methods}

Plant material. Native ninebark was purchased from Outback Nurseries, Hastings, MN. 'Dart's Gold' (yellow-leaved) and 'Monlo' (purple-leaved) were purchased from Bailey Nurseries, St. Paul, MN. Shrubs were planted in 11.4-L containers containing Sunshine Professional Growing Mix (Sungro Horticulture, Seba Beach, Canada). Soil was 
fortified with $35 \mathrm{~g}$ Osmocote $14 \mathrm{~N}-4.2 \mathrm{P}-$ 11.6K (Scotts-Sierra Horticultural Products Co., Marysville, $\mathrm{OH}$ ) and fertilized weekly at $350 \mathrm{ppm}$ with Peters $20 \mathrm{~N}-8.4 \mathrm{P}-16.6 \mathrm{~K}$ (Scotts-Sierra Horticultural Products Co.). Plants were grown outdoors in coldframes (University of Minnesota, St. Paul Campus) to simulate landscape conditions.

Insect material. Beetles were collected from the landscape and raised year-round in the greenhouse on mesh-covered native ninebark, because the beetle is multivoltine. Adults lay egg clusters (5.9 eggs) on the underside of leaves. In the laboratory, development time was $5 \mathrm{~d}$ for eggs and 18.9 $\mathrm{d}$ for larvae (four instars) at $22{ }^{\circ} \mathrm{C}$ with a natural photo period (Wheeler and Hoebeke, 1979). Additionally, beetles were raised on ninebark shoots irrigated in $25-\mathrm{mL}$ plastic water tubes (Syndicate Sales, Kokomo, IN) contained in 14-L rectangular plastic boxes and stored in an incubator at $23{ }^{\circ} \mathrm{C}$ with $16 \mathrm{~h}$ of light.

Feeding preference bioassays: Disc test. On the day of the bioassay, leaves were collected from outside plants (University of Minnesota, St. Paul Campus). Leaves were cut into 1-cm-diameter discs with a disc cutter and six discs were placed in $100 \times 15-\mathrm{mm}$ petri dishes lined with Fisherbrand P5 filter paper (7-cm-diameter; Fisher Scientific, Pittsburgh, PA). The filter paper was kept moist with water. Four beetles were placed in each dish for $24 \mathrm{~h}$, after which each disc was divided into four quadrants and percent missing was quantified by adding the number of bites. Twenty dishes contained native and 'Dart's Gold' discs, 20 contained native and 'Monlo', and 20 contained 'Dart's Gold' and 'Monlo'. The experiment was replicated six times and analyzed by one-way analysis of variance (ANOVA) (combined replicate experiments) (SAS Institute, 2005) and PROC GLM for treatment, replicate, and treatment by replicate interactions (SAS Institute, 2003). When variances were unequal and assumptions of homogeneity were not met (Levene test $P<0.05)$, data were analyzed by Welch ANOVA (SAS Institute, 2005). Means were compared using Tukey's honestly significant difference test and transformed when necessary (SAS Institute, 2005).

Shoot preference bioassays: feeding and oviposition. Shoots of 'Monlo' and native were compared for leaf area consumed and number of eggs on intact shoots. For each replicate experiment, nine cages $\left(30 \mathrm{~cm}^{3}\right.$; BioQuip, Rancho Dominquez, CA) were used, each containing 25 beetles. In each cage, two treatments were placed on opposite sides in plastic 25-mL water tubes (Syndicate Sales, Kokomo, IN). Shoots were added as needed. At $7 \mathrm{~d}$, eggs were counted and percent leaf area consumed was visually quantified by adding the number of bites per leaf to determine the percent leaf area removed per leaf and then calculating a mean for each shoot based on the total number of leaves. The experiment was replicated four times and analyzed by one-way ANOVA (combined replicate experiments) (SAS Insti- tute, 2005) and PROC GLM for treatment, replicate, and treatment by replicate interactions (SAS Institute, 2003). When variances were unequal and assumptions of homogeneity were not met (Levene test $P<0.05$ ), data were analyzed by Welch ANOVA (SAS Institute, 2005). Means were compared using Tukey's honestly significant difference test and transformed when necessary (SAS Institute, 2005).

Long-term performance bioassays: fecundity. Cumulative fecundity of females on three treatments was measured. Newly enclosed beetles were permitted to mate for at least 2 weeks before being placed in containers that were covered with no-see-um netting (97 holes per $\mathrm{cm}^{2}$; Eastex Products, Holbrook, MA) and then covered with plastic wrap and secured with rubber bands. Shoots were changed as needed and eggs were counted weekly and divided by number of females. In the first replicate experiment, females lived for $110 \mathrm{~d}$, but egg laying stopped by $40 \mathrm{~d}$. Consequently, subsequent bioassays were ended at $44 \mathrm{~d}$. At the end of the experiment, beetles were dissected to verify sex and males were identified by the presence of an aedeagus; egg counts were reanalyzed if males were present. The first replicate experiment used 10 containers of native, 10 of 'Monlo', and 10 of 'Dart's Gold', each containing two females. The second replicate experiment used 30 containers of native and 30 of 'Monlo', each containing four females. The third replicate experiment used 10 containers of native, 10 of 'Monlo' and 10 of 'Dart's Gold', each containing four females. Containers in which beetles never laid eggs were excluded from analysis, because lack of egg production indicates poor health, sometimes attributable to presence of pathogens like Nosema (Bauer and Pankratz, 1993). The number of containers with no egg production was independent of treatment. Experiments were analyzed at $44 \mathrm{~d}$ by one-way ANOVA (combined replicate experiments) (SAS Institute, 2005) and PROC GLM for treatment, replicate, and treatment by replicate interactions (SAS Institute, 2003). When variances were unequal and assumptions of homogeneity were not met (Levene test $P<0.05$ ), data were analyzed by Welch ANOVA (SAS Institute, 2005). Means were compared using Tukey's honestly significant difference test and transformed when necessary (SAS Institute, 2005).

Leaf chemistry: anthocyanin, chlorophyll, and nitrogen. Anthocyanin and chlorophyll concentrations were measured with a spectrophotometer. Leaves from five plants of each treatment were collected, preserved on ice, and stored in an ultralow freezer $\left(-20^{\circ} \mathrm{C}\right)$ until extraction. Approximately 0.05 to $0.10 \mathrm{~g}$ of leaf tissue was placed in a homogenization tube and ground for $30 \mathrm{~s}$ in a solution of 1:9 (ammonium hydroxide: acetone) (Environmental Protection Agency, 1994). The extractions were chilled on ice for $2 \mathrm{~h}$ in $12-\mathrm{mL}$ plastic centrifuge tubes and then centrifuged for $20 \mathrm{~min}$ at $270 \times g$. The supernatants were collected and measured with a spectrophotometer. Absorbencies at wavelengths 534, 643, and $661 \mathrm{~nm}$ were measured and used to determine the amounts of chlorophylls A and B and anthocyanins (Sims and Gamon, 2002).

Total nitrogen and Kjeldahl (usable) nitrogen were measured from five plants for each treatment. Leaves were dried in an oven at $65{ }^{\circ} \mathrm{C}$ until crisp, then ground with a 20-mesh sieve stainless steel grinder, redried at $65^{\circ} \mathrm{C}$ for $2 \mathrm{~h}$, cooled in a desiccator, and weighed. Total nitrogen concentration was measured using the Dumas method in which nitrogen contents were combusted with oxygen to form oxides. The oxides were then reduced to $\mathrm{N}_{2}$ by copper and a helium carrier stream measured thermoconductivity. For total nitrogen, $0.15 \mathrm{~g}$ of sample was placed in a gel capsule and analyzed on a LECO 528 analyzer (University of Minnesota Soil Testing Laboratory, St. Paul Campus).

For Kjeldahl nitrogen, $0.15 \mathrm{~g}$ of sample was mixed with $3.5 \mathrm{~mL}$ concentrated $\mathrm{H}_{2} \mathrm{SO}_{4}$, $1.5 \mathrm{~g} \mathrm{~K}_{2} \mathrm{SO}_{4}$, and $7.5 \mathrm{mg}$ selenium. Samples were placed in a $400{ }^{\circ} \mathrm{C}$ heated aluminum box for $1 \mathrm{~h}$ and reacted with salicylate in the presence of hypochlorite and nitroprusside. Turbidity was measured at $660 \mathrm{~nm}$ on a Technicon AutoAnalyzer (University of Minnesota Soil Testing Laboratory, St. Paul Campus).

For all leaf chemistry, experiments were replicated twice and analyzed by one-way ANOVA (combined replicate experiments) (SAS Institute, 2005) and PROC GLM for treatment, replicate, and treatment by replicate interactions (SAS Institute, 2003). When variances were unequal and assumptions of homogeneity were not met (Levene test $P<$ 0.05 ), data were analyzed by Welch ANOVA (SAS Institute, 2005). Means were compared using Tukey's honestly significant difference test and transformed when necessary (SAS Institute, 2005).

\section{Results}

Feeding preference bioassays: disc test. Beetles statistically preferred native $(P<$ $0.0001)$ and 'Dart's Gold' $(P<0.0001)$ over 'Monlo'. However, there was no preference between native and 'Dart's Gold' $(P=$ 0.0743) (Table 1).

Shoot preference bioassays: feeding and oviposition. There was no significant difference in percent leaf area consumed $(P=$ $0.4822)$ or number of eggs laid $(P=0.6223)$ on native or 'Monlo' at $7 \mathrm{~d}$ (Table 2).

Long-term performance bioassays: fecundity. Beetles laid significantly less eggs on 'Monlo' than 'Dart's Gold' at $44 \mathrm{~d}(P=$ 0.0468) (Table 2).

Leaf chemistry: anthocyanin, chlorophyll, and nitrogen. 'Monlo' statistically contained the most anthocyanins compared with native and 'Dart's Gold' $(P<0.0001)$. 'Monlo' contained the most chlorophyll B and 'Dart's Gold' contained the least $(P<0.0001)$. 'Monlo' and native contained significantly more chlorophyll A than 'Dart's Gold' $(P<$ 
Table 1. Percentage of ninebark leaf disc area consumed in $24 \mathrm{~h}$ by adult ninebark beetles.

\begin{tabular}{lccc}
\hline & \multicolumn{3}{c}{ Percent leaf disc area consumed \pm SE } \\
\cline { 2 - 4 } Treatment & Native/Monlo & Monlo/Dart's Gold & Native/Dart's Gold \\
\hline Native & $23.3 \pm 1.4 \mathrm{a}^{\mathrm{z}}$ & - & $22.1 \pm 1.4 \mathrm{a}$ \\
Monlo & $12.5 \pm 1.2 \mathrm{~b}$ & $15.0 \pm 1.2 \mathrm{~b}$ & - \\
Dart's Gold & - & $25.7 \pm 1.5 \mathrm{a}$ & $18.7 \pm 1.2 \mathrm{a}$ \\
$\mathrm{F}(\mathrm{df}), P$ one way & $35.0(1,230),<0.0001$ & $29.9(1,232),<0.0001$ & $3.2(1,226), 0.0743$ \\
$\mathrm{~F}$ (df), $P$ Welch & Levene test $>0.05$ & Levene test $>0.05$ & Levene test $>0.05$ \\
F (df), $P$ model & $11.0(11,220),<0.0001$ & $9.5(11,222),<0.0001$ & $7.0(11,216),<0.0001$ \\
F (df), $P$ treatment & $45.5(1),<0.0001$ & $37.7(1),<0.0001$ & $3.7(1), 0.0569$ \\
F (df), $P$ replicate & $13.2(5),<0.0001$ & $11.3(5),<0.0001$ & $9.6(5),<0.0001$ \\
F (df), $P$ trt*rep & $2.0(5), 0.0865$ & $2.1(5), 0.0657$ & $5.0(5), 0.0002$
\end{tabular}

${ }^{\mathrm{z}}$ Values with different letters are significantly different, Tukey-Kramer honestly significant difference, $\alpha=0.05$.

Table 2. Feeding (percent shoot leaf area consumed) and oviposition (number of eggs), and total fecundity (number of eggs per female) of adult ninebark beetles on ninebark.

\begin{tabular}{lccc}
\hline Treatment & $\begin{array}{c}\text { Percent consumed } \pm \mathrm{SE} \\
(7 \mathrm{~d} \text { choice })\end{array}$ & $\begin{array}{c}\text { No. of eggs } \pm \mathrm{SE} \\
(7 \mathrm{~d} \text { choice })\end{array}$ & $\begin{array}{c}\text { Eggs per female } \pm \mathrm{SE} \\
(44 \mathrm{~d} \text { no choice })\end{array}$ \\
\hline Native & $21.0 \pm 2.4 \mathrm{a}^{\mathrm{z}}$ & $57.4 \pm 16.5 \mathrm{a}$ & $83.2 \pm 9.0 \mathrm{ab}$ \\
Monlo & $18.6 \pm 2.2 \mathrm{a}$ & $68.6 \pm 15.3 \mathrm{a}$ & $66.8 \pm 6.0 \mathrm{~b}$ \\
Dart's Gold & - & - & $104.1 \pm 12.1 \mathrm{a}$ \\
$\mathrm{F}(\mathrm{df}), P$ one way & $0.5(1,54) 0.4822$ & $0.2(1,54) 0.6223$ & $3.2(2,93) 0.0468$ \\
$\mathrm{~F}$ (df), $P$ Welch & Levene test $>0.05$ & Levene test $>0.05$ & Levene test $>0.05$ \\
$\mathrm{~F}$ (df), $P$ model & $5.4(7,48), 0.0001$ & $18.4(7,48),<0.0001$ & $1.8(7,88), 0.0938$ \\
$\mathrm{~F}$ (df), $P$ treatment & $0.2(1), 0.6484$ & $0.5(1), 0.4774$ & $4.9(2), 0.0093$ \\
F (df), $P$ replicate & $11.7(3),<0.0001$ & $42.1(3),<0.0001$ & $1.1(2), 0.3534$ \\
F (df), $P$ trt*rep & $0.7(3), 0.5682$ & $0.6(3), 0.6169$ & $1.7(3), 0.1723$ \\
\hline
\end{tabular}

${ }^{\mathrm{z}}$ Values with different letters are significantly different, Tukey-Kramer honestly significant difference, $\alpha=0.05$.

0.0001). 'Monlo' had statistically less total nitrogen compared with 'Dart's Gold' $(P=0.0283)$ and less Kjeldahl nitrogen compared with native and 'Dart's Gold' $(P=0.0014)$ (Table 3).

\section{Discussion}

Phytochemical analyses showed that purple-leaved 'Monlo' contained higher concentrations of foliar anthocyanins and lower concentrations of nitrogen than 'Dart's Gold'. In other studies, anthocyanins deterred feeding (Harborne and Williams, 2000; Simmonds, 2003), decreased nitrogen (Skillman et al., 1996), and were correlated to increased levels of phenols and tannins (Close et al., 2001; Lee and Lowry, 1980). Consequently, 'Monlo' leaves were probably lower in quality, resulting in fewer eggs in long-term rearing bioassays. In leaf disc bioassays, beetles avoided 'Monlo'; however, in shoot bioassays, no preferences were found. We speculate that cut leaf discs produced more volatile chemicals than intact shoots, which explained why beetles did not show a preference between native and 'Monlo' in shoot bioassays. However, in long-term rearing bioassays, beetles were given no choice and differences in fecundity probably reflected leaf quality.

Similar to our results, several studies reported that increased concentrations of quantitative compounds reduced feeding and growth in specialist herbivores. Condensed tannins from Alaska paper birch (Betula resinifera Britton) were applied to leaves of feltleaf willow [Salix alaxensis (Anderss.)] and quaking aspen. Tannins significantly reduced growth rates of leaf beetles Calligrapha verrucosa (Suffrian) on feltleaf willow and Chrysomela falsa Brown and $C$. crotchi Brown on quaking aspen (Ayres et al., 1997). In a study on Alaska paper birch, pupal weight of spear-marked black moth [Rheumaptera hastata (L.)] was 10 to $20 \mathrm{mg}$ lower when larvae were fed from artificially defoliated trees, which contained four times the amount of tannins and less than two-thirds the amount of nitrogen compared with trees that were not defoliated (Bryant et al., 1993). In a study on Viburnum sp. (a rosaceous relative of ninebark), the specialist viburnum leaf beetle [Pyrrhalta viburni (Paykull)] avoided blackhaw viburnum (Viburnum prunifolium L. 'Early Red'), on which emerging leaves are reddish (Weston and Desurmont, 2002). Koreanspice viburnum (Viburnum carlesii Hemsl.), Fragrant snowball viburnum $(V . \times$ carlcephalum Burkwood ex R.B.Pike), and Judd viburnum $(V . \times$ juddii Rehd.) display reddish leaves in the fall and were resistant to viburnum leaf beetle. Leaf chemical analysis revealed a resistant factor, but it was not determined (Weston et al., 2000).

In addition to breeding plants to have higher amount of quantitative chemicals, breeding plants to contain novel qualitative compounds will reduce feeding and increase mortality in specialist insects. Numerous papers reported that novel compounds not present in host plants of specialist insects reduce feeding and fecundity. For instance, the crucifer flea beetle (Phyllotreta tetrastigma Com.), the turnip flea beetle (P. undulata L.), and the mustard beetle (Phaedon cochleariae $\mathrm{F}$.) refused to feed on cruciferous wallflowers (Erysimum and Cheiranthus sp.), which contained cardenoloids and cardiac glycosides. The yellow-striped flea beetle (Phyllotreta nemorum L.) refused to feed on candytuft (Iberis sp.), which contained cucurbitacins E and I (Nielsen, 1978; Nielsen et al., 1997). A crucifer specialist, imported cabbageworm, did not feed or oviposit on wormseed mustard (Erysimum cheiranthoides L.) (Dimock et al., 1991), a plant containing cardenoloids such as erysimoside and erychroside (Sachdev-Gupta et al., 1990).

\section{Conclusion}

Anthocyanins present in 'Monlo' ninebark reduce preference and fecundity in the specialist ninebark beetle. Understanding that specialist insects avoid feeding on and have reduced fecundity in response to increased levels of quantitative chemicals, as well as novel qualitative chemicals, offers a hypothesis-based method for breeding resistant plants. Because humans do not ingest ornamental plants (unlike crop plants), it is possible to introduce genes for producing

Table 3. Anthocyanin, chlorophyll, and nitrogen contents of ninebark.

\begin{tabular}{|c|c|c|c|c|c|}
\hline \multirow[b]{2}{*}{ Treatment } & \multicolumn{3}{|c|}{$\mathrm{mmol} / \mathrm{g}$ leaf $\pm \mathrm{SE}$} & \multicolumn{2}{|c|}{ Percent $\pm \mathrm{SE}$} \\
\hline & Anthocyanin & Chlorophyll A & Chlorophyll B & Total N & Kjeldahl N \\
\hline$\overline{\text { Native }}$ & $0.4 \pm 0.12 b^{z}$ & $1.7 \pm 0.07 \mathrm{a}$ & $0.4 \pm 0.03 \mathrm{~b}$ & $3.2 \pm 0.08 \mathrm{ab}$ & $3.3 \pm 0.06 \mathrm{a}$ \\
\hline Monlo & $1.6 \pm 0.11 \mathrm{a}$ & $1.9 \pm 0.06 \mathrm{a}$ & $0.6 \pm 0.02 \mathrm{a}$ & $3.0 \pm 0.11 \mathrm{~b}$ & $2.9 \pm 0.09 \mathrm{~b}$ \\
\hline Dart's Gold & $0.2 \pm 0.07 \mathrm{~b}$ & $0.7 \pm 0.09 \mathrm{~b}$ & $0.1 \pm 0.03 \mathrm{c}$ & $3.4 \pm 0.16 \mathrm{a}$ & $3.4 \pm 0.12 \mathrm{a}$ \\
\hline $\mathrm{F}$ (df), $P$ one way & $55.9(2,27),<0.0001$ & $82.0(2,27),<0.0001$ & $116.3(2,27),<0.0001$ & $4.1(2,27), 0.0283$ & $8.4(2,27), 0.0014$ \\
\hline $\mathrm{F}(\mathrm{df}), P$ Welch & Levene test $>0.05$ & Levene test $>0.05$ & $153.8(2,16),<0.0001$ & Levene test $>0.05$ & Levene test $>0.05$ \\
\hline $\mathrm{F}(\mathrm{df}), P$ model & $27.0(5,24),<0.0001$ & $29.8(5,24),<0.0001$ & $41.8(5,24),<0.0001$ & $2.1(5,24), 0.1003$ & $3.8(5,24), 0.0110$ \\
\hline $\mathrm{F}(\mathrm{df}), P$ treatment & $64.0(2),<0.0001$ & $74.3(2),<0.0001$ & $104.5(2),<0.0001$ & $4.0(2), 0.0316$ & $8.3(2), 0.0018$ \\
\hline $\mathrm{F}(\mathrm{df}), P$ replicate & $0.0(1), 0.8499$ & $0.0(1), 0.9636$ & $0.2(1), 0.6995$ & $0.6(1), 0.4539$ & $0.0(1), 0.8917$ \\
\hline $\mathrm{F}(\mathrm{df}), P$ trt*rep & $3.4(2), 0.0488$ & $0.2(2), 0.8040$ & $0.1(2), 0.9548$ & $1.0(2), 0.3976$ & $1.3(2), 0.3049$ \\
\hline
\end{tabular}

${ }^{\mathrm{z}}$ Values with different letters are significantly different, Tukey-Kramer honestly significant difference, $\alpha=0.05$. 
novel toxins and increased polyphenols. Reducing insect damage and insecticide use will foster plant and urban ecosystem health.

\section{Literature Cited}

Ayres, M.P., T.P. Clausen, S.F. MacLean, Jr., A.M. Redman, and P.B. Reichardt. 1997. Diversity of structure and antiherbivore activity in condensed tannins. Ecology 78:1696-1712.

Bajaj, K.L., D. Singh, and G. Kaur. 1989. Biochemical basis of relative field resistance of eggplant (Solanum melongena) to the shoot and fruit borer (Leucinodes orbonalis Guen.). Veg. Sci. 16:145-149.

Bauer, L.S. and S.H. Pankratz. 1993. Nosema scripta N. Sp. (Microsporida: Nosematidae), a microsporidian parasite of the cottonwood leaf beetle, Chrysomela scripta (Coleoptera: Chrysomelidae). J. Eukaryot. Microbiol. 40:135-141.

Berenbaum, M.R. and A.R. Zangerl. 1993. Furanocoumarin metabolism in Papilio polyxenes: Biochemistry, genetic variability, and ecological significance. Oecologia 95:370-375.

Bryant, J.P., P.B. Reichardt, T.P. Clausen, and R.A. Werner. 1993. Effects of mineral nutrition on delayed inducible resistance in Alaska paper birch. Ecology 74:2072-2084.

Close, D.C. and C.L. Beadle. 2003. The ecophysiology of foliar anthocyanin. Bot. Rev. 69:149-161.

Close, D.C., N.W. Davies, and C.L. Beadle. 2001. Temporal variation of tannins (galloylglucoses), flavonols and anthocyanins in leaves of Eucalyptus nitens seedlings: Implications for light attenuation and antioxidant activities. Aust. J. Plant Physiol. 28:1-10.

Dimock, M.B., J.A.A. Renwick, C.D. Radke, and K. Sachdev-Gupta. 1991. Chemical constituents of an unacceptable crucifer, Erysimum cheiranthoides, deter feeding by Pieris rapae. J. Chem. Ecol. 17:525-533.

Dodd, I.C., C. Critchley, G.S. Woodall, and G.R. Stewart. 1998. Photoinhibition in differently coloured juvenile leaves of Syzygium species. J. Expt. Bot. 49:1437-1445.

Donaldson, J.R. and L. Lindroth. 2004. Cottonwood leaf beetle (Coleoptera: Chrysomelidae) performance in relation to variable phytochemistry in juvenile aspen (Populus tremuloides Michx.). Environ. Entomol. 33:1505-1511.

Ehrlich, P.R. and P.H. Raven. 1969. Differentiation of populations. Science 165:1228-1232.

Environmental Protection Agency, Environmental Response Team. 1994. Chlorophyll determination, standard operating procedure \#2030. Environmental Protection Agency, Edison, NJ.

Feeny, P. 1970. Seasonal changes in oak leaf tannins and nutrients as a cause of spring feeding by winter moth caterpillars. Ecology $51: 565-581$
Forkner, R.E., R.J. Marquis, and J.T. Lill. 2004 Feeny revisited: Condensed tannins as antiherbivore defenses in leaf-chewing herbivore communities of Quercus.. Ecol. Entomol. 29:174-187.

Futuyma, D.J. 2000. Some current approaches to the evolution of plant-herbivore interactions. Plant Species Biol. 15:1-9.

Harborne, J.B. and C.A. Williams. 2000. Advances in flavonoid research since 1992. Phytochemistry $55: 481-504$.

Hedin, P.A., J.N. Jenkins, D.H. Collum, W.H. White, W.L. Parrott, and M.W. MacGown 1983 . Cyanidin-3- $\beta$-glucoside, a newly recognized basis for resistance in cotton to the tobacco budworm Heliothis virescens (Fab.) (Lepidoptera: Noctuidae). Cell. Mol. Life Sci. 39:799-801.

Irwin, R.E., S.Y. Strauss, S. Storz, A. Emerson, and G. Guibert. 2003. The role of herbivores in the maintenance of a flower color polymorphism in wild radish. Ecology 84:1733-1743.

Johnson, E.T. and P.F. Dowd. 2004. Differentially enhanced insect resistance, at a cost, in Arabidopsis thaliana constitutively expressing a transcription factor of defensive metabolites. J. Agr. Food Chem. 52:5135-5138.

Krause, G.H., A. Virgo, and K. Winter. 1995. High susceptibility to photoinhibition of young leaves of tropical forest trees. Planta 197:583-591.

Kursar, T.A. and P.D. Coley. 1992. Delayed greening in tropical leaves: An antiherbivore defense? Biotropica 24:256-262.

Lee, D.W. and J.B. Lowry. 1980. Young-leaf anthocyanin and solar ultraviolet. Biotropica 12:75-76.

Nielsen, J.K. 1978. Host plant discrimination within Cruciferae: Feeding responses of four leaf beetles to glucosinolates, cucurbitacins and cardenolides. Entomol. Exp. Appl. 24:41-54.

Nielsen, J.K., L.M. Larsen, and H. Sorensen. 1997. Cucurbitacin E and I in Iberis amara: Feeding inhibitors for Phyllotreta nemorum. Phytochemistry 16:1519-1522.

Painter, R.H. 1951. Insect resistance in crop plants. Macmillan, New York, NY.

Rank, N.E. 1992. Host plant preference based on salicylate chemistry in a willow leaf beetle (Chrysomela aeneicollis). Oecologia 90:95101.

Rhoades, D.F. 1979. Evolution of plant chemical defense against herbivores, p. 3-52. In: Rosenthal, G.A. and D.H. Janzen (eds.). Herbivores: Their interactions with secondary plant metabolites. Academic Press, New York, NY.

Rhodes, D.F. and R.G. Cates. 1976. Toward a general theory of plant antiherbivore chemistry. Recent Advances in Phytochemistry $10: 168-213$
Sachdev-Gupta, K., J.A.A. Renwick, and C.D. Radke. 1990. Isolation and identification of oviposition deterrents to cabbage butterfly, Pieris rapae, from Erysimum cheiranthoides. J. Chem. Ecol. 16:1059-1067.

Santamour F.S., Jr. 1999. Progress in the development of borer resistant white-barked birches. J. Arboriculture 25:151-162.

SAS Institute. 2003. SAS for Windows, version 9.1. SAS Institute, Cary, NC.

SAS Institute. 2005. JMP statistics and graphics guide (including Homogeneity of Variance Tests), version 5.01a. Institute, Cary, NC.

Simmonds, M.S.J. 2003. Flavonoid-insect interactions: Recent advances in our knowledge. Phytochemistry 64:21-30.

Sims, D.A. and J.A. Gamon. 2002. Relationships between leaf pigment content and spectral reflectance across a wide range of species, leaf structures and developmental stages. Remote Sensing of Environment 81:337-354.

Skillman, J.B., B.R. Strain, and C.B. Osmond. 1996. Contrasting patterns of photosynthetic acclimation and photoinhibition in two evergreen herbs from a winter deciduous forest. Oecologia 107:446-455.

Smith, C.M. 2005. Plant resistance to arthro pods. Springer, Dordrecht, The Netherlands. $423 \mathrm{pp}$.

Smith, C.M. and E.V. Boyko. 2007. The molecular bases of plant resistance and defense responses to aphid feeding: Current status. Entomol. Exp. Appl. 122:1-16.

Warren, J.M., J.H. Bassman, and S. Eigenbrode. 2002. Leaf chemical changes induced in Populus trichocarpa by enhanced UV-B radiation and concomitant effects on herbivory by Chrysomela scripta (Coleoptera: Chrysomelidae). Tree Physiol. 22:1137-1146.

Weston, P.A. and G. Desurmont. 2002. Suitability of various species of Viburnum as hosts for Pyrrhalta viburni, an introduced leaf beetle. J. Environ. Hort. 20:224-227.

Weston, P.A., B.C. Eshenaur, and R.E. McNiel. 2000. Viburnum resistance. Amer. Nurseryman 192:51-53.

Wheeler, A.G., Jr. and E.R. Hoebeke. 1979. Biology and seasonal history of Calligrapha spiraeae (Say) (Coleoptera: Chrysomelidae), with descriptions of the immature stages. The Coleopterists Bul. 33:257-267.

Wheeler, A.G., Jr. and E.R. Hoebeke. 1985. The insect fauna of ninebark Physocarpus opulifolius (Rosaceae). Proc. Entomol. Soc. Wash. 87:356-370.

Zavala, J.A. and I.T. Baldwin. 2006. Jasmonic acid signaling and herbivore resistance traits constrain regrowth after herbivore attack in $\mathrm{NiCO}-$ tiana attenuata. Plant Cell Environ. 29:17511760. 